\title{
Energy and Climate Change Mitigation Benefits of Faidherbia albida Agroforestry in Ethiopia
}

\author{
Jonathan D. Haskett ${ }^{1, *}$, Belay Simane ${ }^{2}$ and Caitlin Smith ${ }^{1}$ \\ ${ }^{1}$ Johns Hopkins University, School of Advanced International Studies, Energy Resources and \\ Environment Program, Washington DC, United States. \\ ${ }^{2}$ Addis Ababa University, College of Development Studies, Center for Environment and \\ Development. Addis Ababa, Ethiopia. \\ ${ }^{*}$ Correspondence: \\ Jonathan Haskett \\ Jhaskett314@gmail.com
}

\begin{abstract}
Faidherbia albida trees have an unusual phenology, leafing out during the dry season and shedding leaves at the start of the rainy season. When integrated into agroforestry cropping systems, they provide substantial sustainability benefits, including adding plant nutrients and organic matter to the soil through leaf drop. Dormant during the cropping season, Faidherbia albida does not compete with the crop for light, water or nutrients and contributes nitrogen to the soil under its canopy, enhancing crop productivity. This nitrogen benefit is analyzed in relation to its equivalent in industrially manufactured urea nitrogen fertilizer, expressed in terms of the energy required to manufacture and transport an equivalent quantity of urea fertilizer. This is, in effect, a substitution of solar energy that the Faidherbia albida trees use to obtain nitrogen from the atmosphere, for the fossil fuels used in the industrial manufacture and transport of the urea fertilizer. This energy contribution by the tree, within the food energy and water system, enhances the food production potential of the system, as yields are often increased, and the resilience of the system is enhanced because the soil organic matter increases available water for the plants. This energy contribution to the Ethiopian farming system is estimated as $3.48 \mathrm{GJ}^{-1}$ year $^{-1}$, based on the nitrogen contribution under full canopy cover. Additions of energy to agricultural systems frequently increase productivity and such increases can be realized through the addition of energy provided by Faidherbia agroforestry. Greenhouse gas emissions are avoided by the substitution of solar energy for fossil fuel energy, a climate change mitigation benefit estimated as 0.116 tons $\mathrm{CO}_{2} \mathrm{ha}^{-1}$ year-1. This contribution to climate change mitigation is fundamentally different from sequestration of carbon in biomass or soil organic matter. It is a permanently avoided emission of carbon dioxide into the atmosphere, associated with a particular cropping year, and is not reversible, unlike the benefit of carbon stored in biomass or soil organic matter, that could be released back into the atmosphere. The potential extent of Faidherbia albida agroforestry is substantial and the potential climate change mitigation benefits of its widespread use are great.
\end{abstract}


Keywords: "Food Energy Water Nexus" * "Climate change adaptation and mitigation" * "Faidherbia albida" * "Agroforestry" * "Ethiopia" * "Evergreen Agriculture" * "Nitrogen fertilization" * "Avoided emissions"

\section{Introduction}

The relationship between energy inputs and agricultural productivity is a critical aspect of the food-energy-water nexus. An agroforestry production system based on the acacia species Faidherbia albida has shown great promise to provide an energy input by adding nitrogen to some agricultural systems. In effect, a Faidherbia albida agroforestry production system captures solar energy and converts it to a nitrogen fertilization input, through symbiotic nitrogen fixation in root nodules. This is quantified in the current study as equivalent to an amount of urea nitrogen fertilizer and the energy that would be required to manufacture and transport that amount of fertilizer to the field. The marked increases in crop yield, especially in maize associated with Faidherbia agroforestry (Saka et al., 1994), illustrate a direct link between this tree-based energy input and the potential for enhanced food security, especially since Faidherbia is well adapted to challenging dryland regions such as the Sahel. Faidherbia albida has long been viewed as one of the most important acacia species due to the roles it plays in improving smallholder agriculture in developing countries and in recovering the degraded lands of some of the most difficult dryland landscapes, including in large areas of the Sahel (Barnes and Fagg, 2003). The species is an integral part of a highly successful development strategy known as Evergreen Agriculture (Garrity et al., 2010). The Evergreen Agriculture system is based on the integration of trees, into annual food production and cropping systems, and incorporates mutually supporting strategies that are applied in various combinations at different locations. In addition to cultivating beneficial trees, the Evergreen Agriculture system includes soil conservation structures, water collection, and targeted fertilizer and manure applications. The adoption of Evergreen Agriculture often associated with Faidherbia albida is becoming widespread in Africa, with demonstrated success in improving farmer livelihoods and agricultural sustainability in Ethiopia, Zambia, Malawi, Burkina Faso, and Niger (Garrity et al., 2010) and Faidherbia albida is one of the principle species incorporated into this approach.

Faidherbia albida can achieve heights of $30 \mathrm{~m}$, with trunk diameters up to $2 \mathrm{~m}$. It has a taproot that can reach a depth of 20 meters to access ground water, pull nutrients from the deeper layers of the soil, and cycle these nutrients to the surface layers of the soil (Sileshi,2016; Barnes and Fagg, 2003). Additionally, because Faidherbia albida pods fall at the end of the dry season, they become nutritious forage for livestock when other pastures and foraging sources are typically scarce (Barnes and Fagg, 2003).

The species has an extremely wide natural distribution across large areas of semi-arid Africa, from Senegal to Ethiopia and south through Kenya and Malawi into the Transvaal (Umar et al., 2013). In Ethiopia it is predominantly grown in the agroforestry systems for fodder, mulch, soil improvement and soil conservation. The species is highly unusual in that it exhibits "reverse" phenology, meaning that, unlike most other plant species that grow in areas with a distinct rainy season, Faidherbia albida sheds its leaves and goes dormant at the start of the rainy season, and only goes to full leaf during the dry season (Barnes and Fagg, 2003). This means that the species is out of phase with field crops growing nearby and under its canopy, so it does not compete with these crops for water, light or nutrients. The tree uses a symbiotic relationship with nitrogen 
fixing bacteria living in nodules in its roots to pull nitrogen from the atmosphere. This nitrogen enters the agricultural system primarily when the tree drops its leaves, which then provide numerous benefits to the crops beneath the canopy and within the area of influence of the tree. These benefits include enhanced availability of nitrogen, phosphorus ${ }^{1}$, and soil moisture, plus increased quantities of soil organic matter in the vicinity of the trees (Hadgu, 2009; Sileshi, 2016).

These characteristics of the tree frequently increase crop yields and help to account for the popularity of the species with farmers (Wahl and Bland, 2013). Indeed, there is an extensive literature showing significant yield increases associated with Faidherbia albida for many crops including maize, millet, sorghum, and groundnut (Barnes and Fagg, 2003). Hadgu et al. (2009) found increases in yields of barley in Tigray Ethiopia tied to the impacts of Faidherbia albida. In Malawi, Saka et al. (1994) reported a $280 \%$ increase in maize yields under the canopy of these trees. Shitumbanuma (2012) reported consistent increases in yields of maize, soybeans and groundnuts when these were grown with Faidherbia, but also found concurrently observed decreases in cotton yields. Boffa (1999) reported substantial increases in cereal grain production associated with Faidherbia albida, including increases in millet and sorghum and observed that these increases were often quite pronounced in years with below average rainfall.

One of Faidherbia albida's greatest benefits is the addition of nitrogen to the soil in the area around the tree, primarily through the addition and subsequent decomposition of leaves to the soil surface (Barnes and Fagg, 2003). This quantity of nitrogen can be substantial and a major factor in the increased crop productivity that occurs in proximity to the tree (Sileshi, 2016). A recent study by Yengwe et al. (2018), sampled the total addition of nitrogen in leaf fall over two growing seasons and determined the addition on a per hectare basis, for three age classes of Faidherbia trees. The average value for this addition is used in the current study to provide a realistic baseline for determining the energy and climate mitigation contribution of Faidherbia in agricultural systems.

Although the addition of nitrogen and its benefits for soil fertility and crop growth are widely recognized, Faidherbia albida's corresponding energy input to the farming systems in which they are integrated, has not yet been explored. A part of this contribution can be quantified through the equivalent nitrogen benefit that the trees provide. This nitrogen benefit can be evaluated as an input equal to the energy expended in manufacturing, transporting, and applying the same amount of urea to the field. Viewing nitrogen fertilizer as a quantifiable energy input to agricultural production is well established in the context of an energy analysis of agriculture in the United States (Patzek, 2005; Pimental, 2009), but that analysis has neither been applied to the nitrogen contribution of Faidherbia albida nor been performed in relation to an energy equivalent substitution for urea fertilizer, prior to the current study, based on a review of the literature.

The current study performs these analyses and is part of an ongoing research effort examining the likely response of Ethiopian agricultural to climate change and potential climate shocks (Bakker, et al., 2018). The current framework of this research examines the potential responses of the Ethiopian agricultural system in the interconnected Food - Energy - Water (FEWS) metasystem (Leck, et al., 2015) in which it is embedded. The current study looks at one energy

\footnotetext{
${ }^{1}$ Sileshi (2016) proposes that the phosphorus is provided beneath the tree canopy in part by deep capture and recycling of nutrients by Faidherbia albida.
} 
component of this meta-system and uses an Ethiopian case study as the starting point, consistent with the other aspects of the research effort.

Agriculture in Ethiopia is a core component of the economy. Productivity in this sector is increasingly challenged by depletion of soil nutrients, high levels of livestock grazing pressure, loss of forest cover, population increases, and land use practices that do not ensure long term sustainability (Heffernan et al., 2012). The wide ranges of topographic, climatic factors, parent material and land use have resulted in extreme variability of soils in Ethiopia. Faidherbia albida's contribution to Ethiopian agriculture needs to be understood in the context of Ethiopian soil nutrient status and nutrient depletion. Assessments of nutrient status of Ethiopian soils indicate ranges of $0.9-2.9 \mathrm{~g} \mathrm{~N} \mathrm{~kg}^{-1}$ soil and $0.4-1.10 \mathrm{~g} \mathrm{P} \mathrm{kg}^{-1}$ soil. The calculated national nutrient balances were on average: $47 \mathrm{~kg} \mathrm{~N} \mathrm{ha}^{-1}, 15 \mathrm{~kg} \mathrm{P}_{2} \mathrm{O}_{5} \mathrm{ha}^{-1}$ and $38 \mathrm{~kg} \mathrm{~K}_{2} \mathrm{O} \mathrm{ha}^{-1}$ for the year 2000 (Haileslassie et al., 2005). At the national level, full nutrient balance results indicate a depletion rate of $122 \mathrm{~kg} \mathrm{~N} \mathrm{ha}^{-1} \mathrm{yr}^{-1}, 13 \mathrm{~kg} \mathrm{P} \mathrm{ha}^{-1} \mathrm{yr}^{-1}$ and $82 \mathrm{~kg} \mathrm{~K} \mathrm{ha}^{-1} \mathrm{yr}^{-1}$. The soil nutrient stocks are decreasing except in areas under permanent and vegetable crops. These challenges are exacerbated by the semi-arid climate of the region, which is subject to periodic droughts. The combined impact of these factors compromises Ethiopia's economic productivity and puts parts of the Ethiopian population at risk of food insecurity, malnutrition, and poor health outcomes (Heffernan et al., 2012). Reversing these trends, halting soil degradation, and boosting soil fertility, are top priorities of the Government of Ethiopia (Heffernan et al., 2012).

Ethiopian farmers primarily use urea and diammonium phosphate (DAP) as fertilizers, but only $30 \%$ to $40 \%$ of Ethiopian small farmers apply fertilizers to their fields and often at rates below the recommended rates of application (Abdulkadi et al., 2017). Other sources of added plant nutrition may also be limited as, in some communities, $80 \%$ of animal manure is used as cooking fuel (Abdulkadi et al., 2017). Faidherbia albida, which is native to Ethiopia, can help reverse these trends in soil depletion by providing additional plant nutrition and soil amendment benefits to smallholder agricultural systems. The distribution of Faidherbia albida populations in Ethiopia is not uniform as Faidherbia albida tree populations are lower in the Northern regions of Tigray and Gonder than in the central highlands. The highest populations of Faidherbia albida trees are commonly found along Southern Ethiopia's Great Rift Valley lakes and Awassa, Koka, and Arba Minch drainage systems, as well as in the heavy vertisols around Debre Zeit (Barnes and Fagg, 2003).

\section{Determination of Energy Savings of Faidherbia albida in Fertilizer Equivalents by Calculation}

Faidherbia albida makes significant additions of nitrogen to the soil annually and these additions can be expressed in terms of an equivalent quantity of urea fertilizer (CTFT, 1989). This nitrogen addition is valuable both as a nutrient and as an energy contribution, because the nitrogen provided by the trees substitutes for the energy required to manufacture and transport an equal amount of urea to the field where it would be applied. Yengwe et al. (2018) collected data on the total leaf fall added to the soil surface in maize plots in Zambia and analyzed the nitrogen content over two annual growing seasons. This study converts their value for nitrogen addition to an equivalent amount of nitrogen in the form of urea and uses this value as the basis for calculating both the energy input to the system and the climate mitigation benefit. 
To determine this energy equivalent, it is first necessary to calculate the energy required to manufacture the ammonia, as ammonia is a necessary precursor to manufactured urea. A study by the U.S. Environmental Protection Agency (EPA, 2017), indicated that producing each metric ton of ammonia in a typical fertilizer plant required between30.9 GJ and 39.1 GJ of natural gas. Taking the average of these two values as representative, this study uses $35.0 \mathrm{GJ}$ as the energy used to produce ammonia.

The ammonia produced is then used as a feedstock to produce urea. According to the same EPA study (EPA, 2017), the energy intensity of urea production in a conventional total recycling plant, can be estimated as $6.0 \mathrm{GJ}$ per ton of urea produced. The lower energy requirement for the production of urea as compared with that for ammonia is due, in part, to the energy required to break the triple chemical bond of atmospheric dinitrogen, during the production of ammonia.

To determine the total energy requirement of urea manufacture, the energy intensity of the urea production is added to the energy required to produce the ammonia feedstock used to manufacture urea. This ammonia energy input must be adjusted for the stoichiometric amount of ammonia used in the production of urea, which is 0.567 tons ammonia per ton of urea (Fertilizers Europe, 2000). The total energy used to produce urea is then the sum of the energy used in the production of urea and the energy used in the production of the ammonia feedstock. (Equation 1.)

$$
\begin{gathered}
E_{\text {manufacture }, \text { urea }}=6.0 \frac{\mathrm{GJ}}{\text { ton urea }}+\left(0.567 \frac{\text { ton } \mathrm{NH}_{3}}{\text { ton urea }} * 35.0 \frac{\mathrm{GJ}}{\text { ton } \mathrm{NH}_{3}}\right) \\
E_{\text {manufacture,urea }}=25.9 \frac{\mathrm{GJ}}{\text { ton urea }}
\end{gathered}
$$

This energy value needs to be related to the nitrogen contribution of Faidherbia albida, so it can be appropriately adjusted to capture the energy contribution of the trees to the agricultural system. Yangwe et al. (2018) sampled leaf litter drop in three age classes of Faidherbia trees over two cropping seasons and then used this to determine the litter fall on a per hectare basis. By analyzing the nitrogen content of the leaf litter, they were able to estimate the nitrogen addition in the leaf drop (table 1.)

Table 1: Foliar litterfall quantity and nitrogen return for three age classes of Faidherbia albida trees for two growing seasons (average $\pm S E ; n=3$ ). Data as reported by Yengwe et al. (2018).

\begin{tabular}{|l|l|l|l|l|}
\hline Age of tree & $2014 / 15$ Season & & $2015 / 16$ Season & \\
\hline & $\begin{array}{l}\text { Litterfall } \\
(\mathrm{t} \mathrm{DM} \mathrm{ha}\end{array}$ & $\begin{array}{l}\text { Total } \mathrm{N} \\
\left(\mathrm{kg} \mathrm{ha}^{-1}\right)\end{array}$ & $\begin{array}{l}\text { Litterfall } \\
(\mathrm{t} \mathrm{DM} \mathrm{ha}\end{array}$ & $\begin{array}{l}\text { Total }) \\
\left(\mathrm{kg} \mathrm{ha}^{-1}\right)\end{array}$ \\
\hline 8 & $2.0 \pm 0.2$ & $49.41 \pm 0.19$ & $1.3 \pm 0.1$ & $31.49 \pm 0.12$ \\
\hline 22 & $2.4 \pm 0.4$ & $49.13 \pm 0.57$ & $0.9 \pm 0.1$ & $19.67 \pm 0.23$ \\
\hline
\end{tabular}

The current study uses the averages of these values to determine the average amount of nitrogen returned to the soil in a typical growing season. Using the average of the nitrogen returned by the 
three age classes, the average Faidherbia Albida tree returned 59.59 total $\mathrm{N}\left(\mathrm{kg} \mathrm{ha}^{-1}\right)$ for the 2014/15 season and 45.92 total $\mathrm{N}\left(\mathrm{kg} \mathrm{ha}^{-1}\right)$ for the $2015 / 16$. The average of these two values is $52.76 \mathrm{~kg}$ total $\mathrm{N}$ per hectare and this value is used in the current study as the representative value of nitrogen returned by Faidherbia albida trees to the soil in an annual growing season.

To obtain an equivalent amount of urea fertilizer, the current study used a stoichiometric value of $46 \%$ percent nitrogen in urea $\left(\mathrm{CH}_{4} \mathrm{~N}_{2} \mathrm{O}\right)^{2}$ to convert the nitrogen value of $52.72 \mathrm{~kg} \mathrm{~N} \mathrm{ha}^{-1}$ to a mass-based value of urea fertilizer. Equation 2, below, multiplies the nitrogen value by a factor of $2.17(1 / 0.46)$ to obtain an equivalent amount of urea fertilizer equal to 114.48 Urea $\left(\mathrm{kg} \mathrm{ha}^{-1}\right)$.

$$
114.48 \frac{\mathrm{kg} \text { urea }}{\mathrm{ha}}=52.76 \frac{\mathrm{kg} \mathrm{N}}{\mathrm{ha}} * 1 \frac{\mathrm{kg} \text { urea }}{0.46 \mathrm{~kg} \mathrm{~N}}
$$

To calculate the energy that would be required to manufacture this same amount of urea, equation 3 , below, multiplies this calculated urea equivalent in equation 2 by the energy required to produce manufactured urea from equation 1 . The energy equivalent of the Faidherbia albida contribution in terms of the manufacture of urea is calculated as $2.91 \mathrm{GJ} /$ ha-year (Equation 3).

$$
\begin{gathered}
E_{F A, \text { energy,manufacture,equivalent }}=25.49 \frac{G J}{\text { ton urea }} * 0.114 \frac{\text { ton urea }}{\text { ha-year }} \\
E_{F A, \text { energy,manufacture,equivalent }}=2.91 \frac{G J}{\text { ha-year }}
\end{gathered}
$$

A realistic estimate of the energy equivalent contribution of the Faidherbia albida trees with respect to urea also needs to take into account that the nitrogen from the trees is applied directly to the farm field, but manufactured urea must be transported to the farm for application. This study assumes that the urea will be applied in Ethiopia, in which urea fertilizer is applied at significant rates (Heffernan et al., 2012) and Faidherbia albida is deeply integrated into some of its agricultural system (Hadgu et al. 2011). China is a primary source for urea shipped to Ethiopia (IFDC/AFAP, 2015), and typically, the urea is offloaded at the port of Djibouti and trucked to distribution warehouses in Ethiopia (Heffernan et al., 2012).

To calculate the energy required to transport manufactured urea, this study assumes that the fertilizer is transported first by ship from the Chinese port of Shanghai to the port of Djibouti and next driven by truck from the port of Djibouti to a distribution warehouse in Addis Ababa. Further distribution within Ethiopia is not included in the calculation of the distribution from the warehouse to the individual fields would be prohibitive. Although other fertilizer routes and sources are possible, this route is realistic and captures a significant portion of the fertilizer import supply chain, allowing for a realistic and conservative calculation of the energy used to transport urea from China to Ethiopia.

\footnotetext{
${ }^{2}$ PubChem at https://pubchem.ncbi.nlm.nih.gov/compound/urea\#section=Top
} 
The online shipping distance calculating tool found at sea-distances.org, estimates this ocean voyageto be 5973 nautical miles. Although routes may vary, this estimate is within approximately 50 nautical miles of those obtained from other online commercial shipping distance calculating tools. For example, MarineTraffic.com estimated the most direct route of this voyage to be 6000 nautical miles.

For purposes of calculation, 5973 nautical miles was converted to 11062 kilometers and used in equation 4 to calculate the energy expended to ship the 0.114 ton of urea equivalent provided by Faidherbia albida. Simonsen and Walnum (2011) estimate that $0.172 \mathrm{MJ} /$ ton-km is the energy expended per ton-km of cargo sent by ocean shipping routes.

$$
\begin{gathered}
E_{F A, \text { marine,transport,equivalent }}=0.114 \frac{\text { ton urea }}{\text { ha-year }} * 11062 \mathrm{~km} * 0.172 \frac{\mathrm{MJ}}{\text { ton }-\mathrm{km}} \\
E_{F A, \text { marine,transport,equivalent }}=0.217 \frac{\mathrm{GJ}}{\mathrm{ha-year}}
\end{gathered}
$$

Equation 5 calculates the energy required to transport the manufactured urea by road from the port of Djibouti to distribution warehouses in Ethiopia. For overland transport by truck, the distance from the Djibouti Container Terminal to Addis Ababa, was estimated, using the online distance estimator Distanceto.com, to be $891 \mathrm{~km}$. The International Energy Agency (2009) has estimated the energy required for truck road freight transport in Africa at slightly more than 3.5 $\mathrm{MJ}$ ton- $\mathrm{km}^{-1}$. This study uses a conservative value of $3.5 \mathrm{MJ}$ ton- $\mathrm{km}^{-1}$

$$
\begin{gathered}
E_{F A, \text { road freight transport equivalent }}=\left(0.114 \frac{\text { ton urea }}{\text { ha-year }} * 891 \mathrm{~km}\right) * 3.5 \frac{\mathrm{MJ}}{\text { ton }-\mathrm{km}} \\
E_{F A, \text { road freight transport equivalent }}=0.355 \frac{\mathrm{GJ}}{\mathrm{ha}-\text { year }}
\end{gathered}
$$

The total energy of transportation is the sum of the energy used for marine and road transport (Equation 6).

$$
\begin{gathered}
E_{\text {Total,transport,energy,equivalent }}=0.217 \frac{G J}{h a-y e a r}+0.355 \frac{G J}{h a-y e a r} \\
E_{\text {Total,transport,energy,equivalent }}=0.572 \frac{G J}{h a-y e a r}
\end{gathered}
$$

Thus, the equivalent energy contribution of Faidherbia albida to each hectare of the agricultural system, can be calculated by summing the energy used to manufacture urea fertilizer and the energy used to transport that fertilizer (Equation 7). Equation 7 estimates the total energy equivalent of Faidherbia albida fertilizer contribution to be 3.48 GJ per hectare per year. 
(7)

$$
\begin{gathered}
E_{\text {Total,FA,energy,equivalent }}=2.91 \frac{G J}{\text { ha-year }}+0.572 \frac{G J}{\text { ha-year }} \\
E_{\text {Total,FA,energy,equivalent }}=\mathbf{3 . 4 8} \frac{\mathrm{GJ}}{\text { ha-year }}
\end{gathered}
$$

The contribution of Faidherbia albida can also be quantified in terms of avoided $\mathrm{CO}_{2}$ emissions, or the emissions that would have occurred in manufacturing and transporting the equivalent urea fertilizer. With respect to the $\mathrm{CO}_{2}$ emissions involved in the manufacture of urea, it must be acknowledged that carbon dioxide is a feedstock for the manufacturing process, so some offsetting of $\mathrm{CO}_{2}$ occurs. On a stoichiometric basis, each ton of urea produced consumes 0.733 tons of $\mathrm{CO}_{2}$ (Fertilizer Europe, 2000). The emissions per Giga Joule are $56.0 \mathrm{~kg} \mathrm{CO}_{2}(\mathrm{EPA}$, 2017) and the adjusted emissions from a year of manufacturing are then the total emissions minus the $\mathrm{CO}_{2}$ recovered as feedstock (Equation 8) or 0.079 ton $\mathrm{CO}_{2}$ per ha-year.

$$
\begin{aligned}
E m_{F A, \text { emissions,equivalent,urea }}= & \left(2.91 \frac{\mathrm{GJ}}{\mathrm{ha}-\text { year }} * 0.056 \frac{\text { ton } \mathrm{CO}_{2}}{\mathrm{GJ}}\right)-\left(0.114 \text { ton urea } * 0.733 \frac{\text { ton } \mathrm{CO}_{2} \text { absorbed }}{\text { ton urea }}\right) \\
& E m_{F A, \text { emissions,equivalent,urea }}=0.079 \frac{\text { ton } \mathrm{CO}_{2}}{\text { ha-year }}
\end{aligned}
$$

To obtain the total avoided $\mathrm{CO} 2$ emissions, the emissions from manufacturing must be added to the emissions produced by transporting the fertilizer. A corresponding estimate of the per-km emissions from deepwater ocean transport (equation 9) is $8.4 \mathrm{~g} \mathrm{CO} 2$ per ton-km (McKinnon and Piecyk, 2010), and the total emissions from shipping 0.114 tons of urea from China to Djibouti are calculated in equation 9. Equation 10 calculates the total emissions of trucking 0.114 tons of urea from the Port of Djibouti to the warehouses in Ethiopia. Transport of that quantity of urea for that distance is 101.5 ton-km, while the IEA (2009) value for road freight energy usage of 3.5 $\mathrm{MJ} /$ ton-km, and Edwards et al. (2004) estimate that the value to relate energy expenditure for diesel fuel to $\mathrm{CO} 2$ emissions is $73.54 \mathrm{~kg} \mathrm{CO} 2$ /MJ. Thus, as shown in Equation 11, the total CO2 emissions from transporting the Faidherbia albida equivalent quantity of urea fertilizer is the sum of emissions from marine and road.

$$
\begin{gathered}
E m_{F A, \text { emissions,marine,transport,equivalent }}=\left(0.114 \frac{\text { ton urea }}{\text { ha-year }} * 11062 \mathrm{~km}\right) *\left(8.4 \frac{\mathrm{gCO}}{\text { ton }-\mathrm{km}}\right) \\
E m_{F A, \text { emissions,marine,transport,equivalent }}=10.59 \frac{\mathrm{kgCO}}{\mathrm{ha}-\text { year }}
\end{gathered}
$$

$$
E m_{F A, \text { emissions,road freight,transport,equivalent }}=\left(891 \mathrm{~km} * 0.114 \frac{\text { ton urea }}{\mathrm{ha}-\text { year }}\right) * 3.5 \frac{\mathrm{MJ}}{\text { ton }-\mathrm{km}} * 73.54 \frac{\mathrm{gCO}_{2}}{\mathrm{MJ}}
$$




$$
E m_{F A, \text { emissions,road freight,transport, equivalent }}=26.1 \frac{\mathrm{kgCO}}{\mathrm{ha}-\text { year }}
$$

(11)

$$
\begin{aligned}
& E m_{F A, \text { emissions,total transportation,equivalent }}=10.59 \frac{\mathrm{kgCO}}{\mathrm{ha}-\text { year }}+26.1 \frac{\mathrm{kgCO}}{\mathrm{ha}-\text { year }} \\
& E m_{F A, \text { emissions,total transportation,equivalent }}=36.69 \frac{\mathrm{kg} \mathrm{CO}}{\mathrm{ha}-\text { year }}
\end{aligned}
$$

Finally, the emissions avoided by gaining the nitrogen input from the Faidherbia trees rather than from the application of manufactured urea can be calculated by adding the emissions from the urea manufacturing process to the emissions from transporting the urea. The annual total avoided emissions from the nitrogen provided by Faidherbia albida is 0.116 tons $\mathrm{CO} 2$ per hectare, as shown in Equations 12.

$$
\begin{gathered}
E m_{F A, \text { emissions,total,equivalent }}=79.4 \frac{\mathrm{kgCO}}{\mathrm{ha}-\text { year }}+36.69 \frac{\mathrm{kgCO}}{\mathrm{ha}-\text { year }} \\
E m_{\mathrm{FA}, \text { emissions,total,equivalent }}=\mathbf{0 . 1 1 6} \frac{\text { ton } \mathrm{CO}_{2}}{\mathrm{ha}-\text { year }}
\end{gathered}
$$

\section{Discussion}

On a per hectare basis through the contribution of nitrogen alone, Faidherbia albida could make an annual equivalent energy contribution of $3.48 \mathrm{GJ} /$ ha in Ethiopia. Such a contribution can facilitate significant improvements in agricultural development such as enhanced productivity, enhanced crop nutrition, and adaptation to climate change for farming systems, as well as a contribution to climate change mitigation. These aspects are discussed further below. It is important to note that in different regions and under different climate and environmental circumstances, there is likely to be significant variation in the nitrogen additions of Faidherbia albida to cropping systems. The values arrived at in this study, while based on sound research, and likely to have broad application, should not be regarded as precisely prescriptive in each instance, inside or outside of Ethiopia. Future research can build on the principles described in the current study to arrive at accurate assessments of the energy and climate contributions of Faidherbia albida in other regions and circumstances.

A crucial factor for this study is the quantity of nitrogen added to the soil by the leaf litter from the Faidherbia albida trees. Earlier research has provided estimates that were far higher than the value used in the current study. One such estimate by the Centre Technique Forestier Tropical (CTFT, 1989) estimated an annual addition of $480 \mathrm{Kg} \mathrm{N} \mathrm{ha}^{-1}$ and linked this to an equivalent addition of 1.15 tons of urea nitrogen fertilizer. Dancette and Poulin (1969), cited in Umar et al. (2013) provide an estimate of $300 \mathrm{~kg} \mathrm{~N} \mathrm{ha}^{-1}$ added by Faidherbia trees annually. A study in Zambia by Yengwe, at al. (2017) estimated that, over a 35-year time span, a Faidherbia albida tree contributed between 61 and $78 \mathrm{~kg} \mathrm{~N} \mathrm{ha}^{-1}$ year $^{-1}$, with mature trees contributing an estimated $100 \mathrm{Kg} \mathrm{N} \mathrm{ha}^{-1}$ year $^{-1}$. By contrast, Umar, et al. (2013), in another study in Zambia, estimated that a Faidherbia tree would provide $39 \mathrm{~kg} \mathrm{~N} \mathrm{ha}^{-1}$ annually. Umar et al. (2013) also stated that, 
for small holders, this nitrogen addition could be viewed as a direct substitute for purchased mineral fertilizer. The value used for calculation in the current study is a conservative estimate that is consistent with the range of values reported in recent work on nitrogen additions from Faidherbia trees and based on data from direct measurements using more recent investigative techniques.

\section{Manufacturing energy calculations}

The current study uses the values set out by the EPA (2017) to calculate the energy expended to manufacture urea. The range of values for the production of ammonia was 30.9 to $39.1 \mathrm{GJ} /$ ton of ammonia depending on the age and practices of the manufacturing facility. The current study used the average of this range, $35.0 \mathrm{GJ} /$ ton of ammonia as representative on the recommendation of one of the EPA study's authors (Kermeli, 2018, personal communication). The same EPA (2017) study provided a value of $6.0 \mathrm{GJ}$ per ton of urea produced that is used in the current study. Earlier studies of energy consumption for ammonia production cited by Patzek (2005) found a value of $34.5 \mathrm{GJ} /$ ton for modern $\mathrm{NH}_{3}$ production, and Patzek (2005) found values ranging from $35.6 \mathrm{GJ} /$ ton to $58 \mathrm{GJ} /$ ton reported in the pre -1986 literature with values as high as $65 \mathrm{GJ} /$ ton reported in the literature of small pre-1969 plants. The energy required to produce urea, citing the values of $35.6 \mathrm{GJ} /$ ton value for the production of ammonia and $7.5 \mathrm{GJ} /$ ton for urea from the same source, is reported in the existing literature as $42 \mathrm{GJ} /$ ton of urea. However, this assumes that on a per ton basis the energy expenditures are directly additive and does not account for the stoichiometric relationship that occurs in the actual consumption of ammonia in the urea manufacturing process.

The current study, however, accounts for this stoichiometric relationship by adjusting the energy consumed in urea production by 0.567 ton of ammonia, which is the ammonia consumed per ton of urea produced (Fertilizer Europe, 2000; A. Kermeli, 2018, personal communication). When this relationship is included in calculations based on the values presented by Patzek, the energy value for the ammonia used in the production of a ton of urea is $20.2 \mathrm{GJ} /$ ton urea. When this 20.2 $\mathrm{GH} /$ ton urea is added to the $7.5 \mathrm{GJ} /$ ton urea used in the manufacturing process, this study obtains a value of $27.7 \mathrm{GJ} /$ ton urea manufactured. This calculated value is much closer to the value of $25.49 \mathrm{GJ} /$ ton derived from the values reported by EPA (2017).

\section{Transportation energy calculations}

The values used in this study to calculate the energy used in transporting urea fertilizer are not identical to those found in other sources. Standard values for energy consumption for freight transport were reported by Deutsche Bahn (Deutsche Bahn, - Table: "Specific primary energy consumption by trips and transports of DB Group", https://www.deutschebahn.com/en/group/ataglance/facts figures-1776344, site accessed $7 / 20 / 2018)$. For truck freight energy consumption, the value of $1.31 \mathrm{MJ} /$ ton-km closely matches the value of $1.33 \mathrm{MJ} / \mathrm{ton}-\mathrm{km}$ published by Simonsen and Walnum (2011) but both are far below the $>3.5 \mathrm{MJ} /$ ton-km for Africa found in the IEA (2009). The IEA (2009) value was specific to Africa and it was used in the current study.

The value for ocean freight provided by Deutsche Bahn was $0.09 \mathrm{MJ} / \mathrm{ton}-\mathrm{km}$ and substantially lower than the $0.172 \mathrm{MJ} / \mathrm{ton}-\mathrm{km}$ published by Simonsen and Walnum (2011). Values reported in Gleick et al. (2012) are substantially higher than either of these values, and Gleick cites DOE and 
Natural Resources Canada with values of $0.37 \mathrm{MJ} / \mathrm{ton}-\mathrm{km}$ for ocean freight transport and 3.5 $\mathrm{MJ} /$ ton-km for heavy truck transport (also consistent with the IEA (2009). In this study we use the values of Simonsen and Walnum (2011) because they are more conservative than those cited by Gleick and likely to underestimate, not overestimate, the equivalent energy input benefit to the farming system. Further, these values were selected over the more conservative values of Deutsche Bahn because sourcing from Simonsen and Walnum includes explicit external peer review. Evidently further research on this energy expenditure will be needed in the future, focused specifically on the transportation of urea fertilizer and specifying both the typical type and displacement of the ship transport and the likely energy expenditure of the typical trucking journey from the port of Djibouti to Addis Ababa.

\section{Energy analysis of the fertilizer contribution to the farming system}

One of the factors that separates agriculture in the developing world from agriculture in the industrialized world is the difference in energy inputted to the farming systems and the crop yields, per unit of energy invested, from each system. Using corn as a comparison crop, Pimental (2009) found that corn production in India and Indonesia had an energy input to output ratio of 1:1.08 but corn production in the United States had an energy input to output ratio of 1:4.11 with a corresponding five-fold increase in crop yield. The energy input, occurring through mechanization and the very large application of fertilizers in the United States, is responsible for much of this massive increase in crop yield. In the energetics of this study, part of the increase in yield comes from what is essentially an increase in efficiency, where energy in the form of animal traction and human labor that is less productive in cultivating and harvesting, is substituted for by more productive mechanical and fossil fuel energy, in the United States. However, with respect to nutrient inputs, the energy contribution of nitrogen virtually doubles between the two systems, with the energy value of nitrogen in India and Indonesia reported as $1200 \mathrm{kCal} \times 1000 \mathrm{ha}^{-1}$ and as $2480 \mathrm{kCal} \times 1000 \mathrm{ha}^{-1}$ for the United States (Pimental, 2009). This is an energy input increase achieved through significant additions of fossil fuel, in the form of natural gas, used to produce nitrogen fertilizer.

While a corresponding input of fertilizer energy would probably also increase yields in the developing world, there are several obstacles to realizing this benefit. One such obstacle is the lack of farmer financial resources, or sometimes shortages of foreign exchange on a national level, to buy fertilizer. This is compounded by the logistical difficulty in transporting and distributing fertilizer to the small farmers who need it. In addition, the heavy reliance of nitrogen fertilizer production on fossil fuel, which is a primary energy input into this production system, means that there will be significant emissions of greenhouse gases, which have negative consequences for the earth's climate. Given the energetics of breaking the triple atomic bond of diatomic Nitrogen, it is currently not cost-effective to use renewable energy, and not natural gas, in the nitrogen fertilizer production system (Pimental, 2009).

Nevertheless, the agricultural benefits to be gained from adding nitrogen fertilization are so substantial that an alternative method of bringing this energy into the Ethiopian agricultural system would be quite useful. This study shows that incorporating Faidherbia albida into the Ethiopian farming systems can provide this energy input in a manner that is effective and environmentally beneficial, from a climate change point of view. Due to its reverse phenology, Faidherbia is out of phase with the planted crops, so is able to harvest what would otherwise be agriculturally unused photosynthetically active radiation incident from the cropping area during 
the unplanted dry season and use parts of this energy to fix nitrogen from the atmosphere. This occurs as Faidherbia provides part of the resulting photosynthate to the symbiotic bacteria in the roots. These roots then break the energy-intensive nitrogen triple bond in ammonia, without using fossil fuels and provide the resulting nitrogen to the tree. The tree is not unique in this ability to obtain nitrogen from the atmosphere but is unique in that it can take advantage of this nitrogen fixation in areas where alternatives such as "green manure," or nitrogen-fixing crops would be infeasible because these methods can provide nitrogen by depleting the soil of moisture and sacrificing an entire cropping cycle. Faidherbia albida trees, conversely, are able to expand the net quantity of energy entering the system by converting it into a usable form, rather than letting it escape from the system as radiant heat. This increase in energy input is equivalent to the additional energy of fertilizer that is often made available through large investment of fossil fuel, but without the expense or climate consequences of fossil fuel consumption.

A process of adding energy to the agricultural system through the addition of nitrogen via biological nitrogen fixation, through the integration of Faidherbia albida into the agricultural system, could increase yields in large areas of Africa (and elsewhere) in the developing world but without the need to develop corresponding manufacturing and transportation infrastructure to support this increase and without the corresponding greenhouse gas emissions. This increase might also be enhanced by the development of other components of the agricultural system, such as the development of locally adapted, dryland crop varieties that could withstand the restricted quantity and variability of rainfall, while taking advantage of the increased nutrient availability due to introduction of this agroforestry system. The combination of more productive and adaptive varieties could be further enhanced by the adoption of water capture and soil conservation methods (Reij et al. 2009), as well as highly targeted, locally-appropriate fertilizer application technologies for other limiting nutrients, once the fundamental nutrient base for crop production has been provided, by the Faidherbia trees. In these ways there is the potential for Faidherbia albida to provide the energy/nutrient foundation for a marked, discontinuous increase in crop yields.

\section{The energy substitution of Faidherbia produces additional benefits beyond $\mathbf{N}$ fertilization}

In addition to the avoided emissions, there are significant differences between the nitrogen energy expenditures that provide manufactured nitrogen fertilizer to the agricultural system and those used by Faidherbia albida to add nitrogen to the system. The nitrogen from Faidherbia enters the agricultural system when the trees lose their leaves at the beginning of the rainy season and the decomposing leaves deposit both the fixed nitrogen that was used to grow the leaves and the leaves' carbon component into the soil, leading to increases in soil organic matter in proximity to the tree (Sileshi, 2016; Hadgu et al. 2009). This increase in soil organic matter has significant implications for crop productivity, agricultural system food security and climate change adaptation. The net increase in organic matter, especially in agricultural systems from which it has been depleted, both greatly enhances the effectiveness of added nitrogen fertilizer (Marenya and Barret, 2009) and improves other soil properties, such as plant available water and cation exchange capacity. The increase in soil organic matter also favors increased plant productivity and crop resistance to drought (Bot and Benites, 2005), both of which are critical components to maintaining sustainable yields for food security and to facilitating adaptation to climate change, which is projected to result in greater variability in rainfall and increased instances of drought (Kandji, 2006). 
The energy input of the Faidherbia tree thus provides multiple system-wide benefits ${ }^{3}$ beyond the addition of nitrogen that cannot be matched by the equivalent energy input provided by chemical nitrogen fertilizer. These additional systemic benefits are more difficult to quantify than the fertilizer energy use equivalence but should be considered when assessing the potential of Faidherbia albida to improve agricultural systems in the context of rural development.

\section{The fertilizer substitution of Faidherbia provides climate change mitigation benefits}

As illustrated in equations 8 through 12, above, there are significant avoided carbon dioxide emissions associated with using nitrogen provided by Faidherbia instead of nitrogen from manufactured urea. This study calculates avoided $\mathrm{CO}_{2}$ emissions of 0.116 tons per hectare per year. Where large-scale integration of Faidherbia takes place as a strategy for agricultural development, this contribution to climate change mitigation could be significant. For example, the late Prime Minister Meles Zenawi of Ethiopia announced at the Durban Climate Change Convention in December 2011, that the Ethiopian government would work to establish a hundred million Faidherbia albida trees Ethiopia through engagement with smallholder agriculture (https://allafrica.com/stories/201211190086.html, site accessed 8/15/2018). Achieving this level of integration would result in real contributions to Ethiopia's pledge in its Nationally Determined Contribution to reduce emissions by $64 \%$ below business-as-usual projections by 2030 . Such a contribution would be significant in both ensuring agricultural productivity continues to rise to meet a growing human population and in showing that climate mitigation can also support the achievement other national development benefits.

The increasing yields achieved in industrialized agriculture have come at a price of increased emissions of greenhouse gases, especially $\mathrm{CO}_{2}$ and methane $\left(\mathrm{CH}_{4}\right)$, making agriculture a major contributor to climate change (IPCC, 2014). Nitrogen fixation by human chemical means has now altered the global nitrogen cycle (Steffen, et al., 2005). At the same time, there is a need to increase agricultural productivity to feed the growing human populationin an environmentally sustainable way in part by closing the yield gap, between the potential productivity of the agricultural system and its current productivity (Foley, 2011). Faidherbia albida can help accomplish these dual goals, as it provides nitrogen fertilization, without any additions of heattrapping gases to the atmosphere. As such, Faidherbia albida provides an alternative development pathway to closing of the yield gap, while having a positive effect on the climate. As this closing would otherwise need to be accomplished, in part, by the addition of fossil fuel produced nitrogen fertilizer, the contribution of Faidherbia effectively substitutes for the chemical fertilizer input (Umar et al. 2013). Thus, the emissions associated with the manufacture and transportation of the fertilizer to the point of application can legitimately be counted as an avoided emission that helps mitigate climate change in combination with the carbon sequestered in the trees' biomass and in the increases in soil organic matter associated in the trees' areas of influence. Indeed, increases in carbon sequestered above and below ground in Evergreen Agriculture systems that include Faidherbia, or other tree species that provide a fertilizer benefit, can be as much as an order of magnitude greater than that of conservation farming alone (Garrity et al. 2010).

\footnotetext{
${ }^{3}$ By increasing the soil organic matter, the tree provides multiple benefits to the cropping system including, increased plant available water, increased fertilizer use efficiency, increased water use efficiency, increased cation exchange capacity and improved ease of cultivation.
} 
Faidherbia also sequesters carbon in its biomass and increases the levels of soil organic matter within its area of influence. These benefits of sequestration are fundamentally different from avoided emissions, as carbon sequestered in soil is released if the tree is cut or burned or if the soil brought under more intensive tillage. Conversely, the avoided emissions resulting from fertilizer substitution are permanent, as they are associated with a specific fertilizer application in a specific cropping cycle in a particular year. They are thus equivalent to avoided emissions on par with an increase in energy efficiency at a factory that reduces emissions in a given year. As such any tradable carbon credits associated with the trees' avoided emissions should be considered as permanent, fully fungible credits and thus different from other land use credits.

Farmer Managed Natural Regeneration (FMNR $)^{4}$, is a highly successful approach to the regeneration of degraded land and to generating productivity increases centered on the cultivation of trees in small-holder agricultural systems (Reij et al., 2009). Since Faidherbia albida is a key species used in this approach, the area of FMNR on a landscape can provide some insight into the potential scale that could be achieved through the integration of Faidherbia albida into smallholder agricultural landscapes. Based on the analysis of high-resolution, remote sensing imagery for the Maradi-Zinder region of Niger, Reij et al. (2009) estimate that FMNR was practiced over 4,828,500 ha. Using this figure as a starting point in a thought experiment, it is assumed, conservatively, that Faidherbia is present in half of this area and that the Faidherbia tree cover is half of that of the Yengwe (2018) study. The energy for transportation will likely be greater to this area than for typical areas of Ethiopia, but for purposes of this thought experiment, the same value is used to produce a conservative estimate. Based on the calculations suggested in the current study, Faidherbia albida covering half the FMNR land used in Niger would result in an annual injection of energy equal to 4.2 million GJ and 0.28 million tons of avoided $\mathrm{CO}_{2}$ emissions.

$$
\begin{gathered}
4.2 \text { million } \frac{G J}{\text { year }}=\left(2,414,250 \mathrm{ha} * 3.48 \frac{\mathrm{GJ}}{\mathrm{ha}-\text { year }}\right) / 2 \\
0.28 \text { million } \frac{\text { ton } \mathrm{CO}_{2}}{\text { year }}=\left(2,414,250 \mathrm{ha} * 0.116 \frac{\text { ton } \mathrm{CO}_{2}}{\text { ha-year }}\right) / 2
\end{gathered}
$$

The avoided emissions are at a significant scale such that they could help Niger fulfill the pledges in its Nationally Determined Contribution plan to both reduce GHG emissions by at least $3.5 \%$ by 2030 and to scale up sustainable land management practices over all agroecological $\operatorname{areas}^{5}$ (Niger, INDC, 2015). At the scale of adoption of Faidherbia albida that is already occurring in large areas of the Sahel and elsewhere in Sub-Saharan Africa, it seems reasonable to propose that the avoided emissions produced by the trees could also potentially make contributions to the climate mitigation efforts of some countries including, Ethiopia.

Similarly, the Zambian Conservation Farming Unit (CFU) estimates that Faidherbia albida is now cultivated on 300,000 hectares of farmland with recommended planting rates likely providing full canopy cover (Garrity et al. 2010). As in the Niger example, the energy for

\footnotetext{
${ }^{4}$ See Reij et al. (2009) for a more complete description of the method, adoption and impact of Farmer Managed Natural Regeneration.

${ }^{5}$ Agriculture Forestry and Other Land Use (AFOLU) is a priority sector for climate mitigation under the Intended Nationally Determined Contribution plan of Niger (INDC, Niger, 2015).
} 
transportation will likely be greater to this area than for Ethiopia, but to be consistent, the same value is used to produce a conservative estimate. Based on the current study figures, the energy input of the Faidherbia albida trees cultivated on the 300,000 hectares in Zambia is estimated in this thought experiment to be 1.04 million GJ per year and the avoided emissions to be 50,400 tons of $\mathrm{CO}_{2}$ per year.

$$
\begin{aligned}
& 1.04 \text { million } \frac{G J}{\text { year }}=300,000 \text { ha } * 3.48 \frac{G J}{h a-\text { year }} \\
& 34,800 \frac{\text { ton } \mathrm{CO}_{2}}{\text { year }}=300,000 \text { ha } * 0.116 \frac{\text { ton } \mathrm{CO}_{2}}{\text { ha-year }}
\end{aligned}
$$

Further, the Faidherbia nitrogen is estimated to displace 34,200 tons of manufactured urea annually. At a price urea fertilizer of $\$ 200^{6}$ per ton of urea fertilizer the Faidherbia leads to savings of $\$ 6.8$ million USD in fertilizer that would not need to be purchased.

$$
\$ 6.8 \frac{\text { million } U S D}{\text { year }}=300,000 \text { ha } * 0.114 \frac{\text { ton urea }}{\text { ha-year }} * 200 \frac{\$ U S D}{\text { ton }- \text { urea }}
$$

\section{The contribution of Faidherbia albida would also have multiple economic benefits}

Finally, it is important to note that adding nitrogen from Faidherbia albida is likely to have multiple economic benefits, some of which are specific to integrating trees into the agricultural system. In addition to the positive impacts on crop productivity, food security, and decreases in vulnerability to drought impacts that are discussed throughout this study, Faidherbia albida provides tangible financial savings to the farmers, governments, and other stakeholders in the economic system. Governments in Sub-Saharan Africa sometimes subsidize manufactured fertilizer, so procuring the nitrogen fertilizer by cultivating Faidherbia albida instead of from imported manufactured urea would reduce government's foreign exchange expenditures. The use of the trees would also avoid an unstable economic dynamic in which farmers are dependent on government subsidies to use nitrogen fertilizers to a degree such that the curtailment of said subsidies would lead to abrupt drop in fertilizer use, crop productivity, and potentially, a severe economic shock. By contrast, Faidherbia trees are long lived, provide a consistent and reliable source of nutrients, and are decoupled from both the world price of fertilizer and the economic policies of the government. Malawi has adopted policies that reflect the benefits of substituting tree-based sources of nitrogen for subsidized chemical fertilizer (Garrity et al., 2010) and other governments in the region may also recognize these benefits.

\section{Conclusion}

Faidherbia albida's reverse phenology enables it to provide nitrogen nutrition and soil organic matter additions to farming systems that function as a significant contribution of useable energy to these same systems. The trees' energy input also provides a vehicle to ramp up agricultural productivity, similar to the way in which agriculture productivity increased in the industrialized world through increased energy inputs. In Ethiopia, this additional energy benefit occurs as the

\footnotetext{
${ }^{6}$ International Raw Materials Ltd. reported a global granular urea price of \$263 per metric ton on July 26, 2018. https://www.irmteam.com/
} 
trees' decomposing leaves add nitrogen equivalent to the nitrogen contained in a substantial quantity of urea fertilizer and increase water availability to the crops. The development benefits, in terms of increased agricultural productivity and adaptation to climate change, are substantial. Additionally, the trees use solar radiation as their energy input, and this solar energy displaces the natural gas used to both manufacture urea and the fossil fuels used to transport the manufactured fertilizer to the point of use. The trees thus lead to substantial avoided greenhouse gas emissions, meaning that if Faidherbia albida trees were cultivated over large areas their avoided emissions could make a significant annual contribution to national efforts to mitigate climate change.

\section{Citations}

Abdulkadi, Birhan, Sofia Kassa, Tmesgen Desalegn, Kassu Tadesse, Mihreteab Haileselassie, GirmaFana, ToleraAbera, Tilahun Amede, and Degefie Tibebe. "Crop Response to Fertilizer Application in Ethiopia: A Review.” In: A Review of Soil Fertility Management and Crop Response to Fertilizer Application in Ethiopia: Towards Development of Site- and ContextSpecific Fertilizer Recommendation. CIAT Publication No. 443. Center for International Tropical Agriculture (CIAT), 2017.

Haileslassie, Amare, Joerg Priess, Edzo Veldkamp, Demil Teketay, and Jan Peter Lesschen. “Assessment of Soil Nutrient Depletion and Its Spatial Variability on Smallholders' Mixed Farming Systems in Ethiopia Using Partial versus Full Nutrient Balances.” Agriculture, Ecosystems \& Environment 108, no. 1 (June 2005): 1-16.

https://doi.org/10.1016/j.agee.2004.12.010.

Bakker, Craig, Benjamin F. Zaitchik, Sauleh Siddiqui, Benjamin F. Hobbs, Elena Broaddus, Roni A. Neff, Jonathan Haskett, and Cindy L. Parker. "Shocks, Seasonality, and Disaggregation: Modelling Food Security through the Integration of Agricultural, Transportation, and Economic Systems.” Agricultural Systems 164 (July 2018): 165-84. https://doi.org/10.1016/j.agsy.2018.04.005.

Barnes, Richard, and Christopher Fagg. Faidherbia Albida: Mongraph and Annotated Bibliography. Tropical Forestry Papers 41. Oxford Forestry Institute, 2003.

Boffa, Jean-Marc. Agroforestry Parklands in Sub-Saharan Africa. FAO Conservation Guide 34. Rome: Food and Agriculture Organization of the United Nations, 1999.

Bot, Alexandra, and José Benites. The Importance of Soil Organic Matter: Key to DroughtResistant Soil and Sustained Food Production. FAO Soils Bulletin 80. Rome: Food and Agriculture Organization of the United Nations, 2005.

CTFT (Centre Technique Forestier Tropical). Faidherbia albida (Del.) A.Chev. (Synonym Acacia albida el.): A monograph. Centre Technique Forestier Tropical (France) and Technical Centre for Agricultural and Rural Cooperation (Netherlands) (1989) 66 [En (original Fr), 189 ref., many photographs, tables, diagrams and drawings] 
Dancette C., Poulain, JF. Influence of Acacia albida on pedoclimatic factors and crop yields. African Soils. 14 (1969):143-184.

Deutsche Bahn, - Table: "Specific primary energy consumption by trips and transports of DB Group", . https://www.deutschebahn.com/en/group/ataglance/facts_figures-1776344, site accessed $7 / 20 / 2018$

Edwards, Robert, Vincent Mahieu, Jean-Claude Griesemann, Jean-François Larivé, and David J. Rickeard. "Well-to-Wheels Analysis of Future Automotive Fuels and Powertrains in the European Context," 2004. https://doi.org/10.4271/2004-01-1924.

EPA, United States Environmental Protection Agency. Energy Efficiency and Cost Saving Opportunities for Ammonia and Nitrogenous Fertilizer Production. Authors: Kermeli, K., E. Worrell, G. Wina, and M. Corsten, (2017) Document Number 430-R-17002

Fertilizer Europe, 2000. Best Available Techniques for Pollution Prevention and Control in the European Fertilizer Industry. Booklet No. 5 of 8: PRODUCTION OF UREA and UREA AMMONIUM NITRATE, 2000 Edition. Fertilizer Europe.

Foley, Jonathan A., Navin Ramankutty, Kate A. Brauman, Emily S. Cassidy, James S. Gerber, Matt Johnston, Nathaniel D. Mueller, et al. "Solutions for a Cultivated Planet." Nature 478, no. 7369 (October 2011): 337-42. https://doi.org/10.1038/nature10452.

Garrity, Dennis Philip, Festus K. Akinnifesi, Oluyede C. Ajayi, Sileshi G. Weldesemayat, Jeremias G. Mowo, Antoine Kalinganire, Mahamane Larwanou, and Jules Bayala. "Evergreen Agriculture: A Robust Approach to Sustainable Food Security in Africa." Food Security 2, no. 3 (September 2010): 197-214. https://doi.org/10.1007/s12571-010-0070-7.

Gleick, Peter. H., Lucy Allen, Juliet Christian-Smith, Michael J. Cohen, Matthew Heberger, Jason Morrison, Meena Palaniappan, and Paul Schulte. The World's Water Volume 7: The Biennial Report on Freshwater Resources. Vol. Vol 7. The World's Water. Island Press, Pacific Institute for Studies in Development, Environment and Security, The Center for Resource Economics, 2012.

Hadgu, Kiros M., Lammert Kooistra, Walter A. H. Rossing, and Ariena H. C. van Bruggen. "Assessing the Effect of Faidherbia albida Based Land Use Systems on Barley Yield at Field and Regional Scale in the Highlands of Tigray, Northern Ethiopia." Food Security 1, no. 3 (September 1, 2009): 337-50. https://doi.org/10.1007/s12571-009-0030-2.

Hadgu, Kiros Meles. "Current Extent of Evergreen Agriculture and Prospects for Improving Food Security and Environmental Resilience in Ethiopia.” International Journal of Agricultural Sciences 1(1) (December 2011): 006-016. 
Heffernan, Peter, Porfirio Fuentes, and Joshua Ariga. "Ethiopia Fertilizer Assessment." International Fertilizer Development Center, December 2012, 46.

International Energy Agency (IEA). Transport Energy and CO2: Moving towards Sustainability. OECD, 2009. https://doi.org/10.1787/9789264073173-en.

IFDC/AFAP (International Fertilizer Development Center/African Fertilizer Agribusiness Partnership), 2015. Source Cited in the preparation of "African Fertilizer Map". A. Harrison, Project Manager. Sponsored by Saudi Arabian Mining Company and International Fertilizer Association, African Fertilizer Agribusiness Partnership, International Fertilizer Development Center and AfricanFertilizer.org

IPCC, 2014: Climate Change 2014: Mitigation of Climate Change. Contribution of Working Group III to the Fifth Assessment Report of the Intergovernmental Panel on Climate Change [Edenhofer, O., R. Pichs-Madruga, Y. Sokona, E. Farahani, S. Kadner, K. Seyboth, A. Adler, I. Baum, S. Brunner, P. Eickemeier, B. Kriemann, J. Savolainen, S. Schlömer, C. von Stechow, T. Zwickel and J.C. Minx (eds.)]. Cambridge University Press, Cambridge, United Kingdom and New York, NY, USA.

Kandji, Serigne Tacko, Louis Verchot, and Jens Mackensen. "Climate Change and Variability in the Sahel Region:" United Nations Environment Program, World Agroforestry Centre, 2006.

Leck, Hayley, Declan Conway, Michael Bradshaw, and Judith Rees. "Tracing the Water-EnergyFood Nexus: Description, Theory and Practice: Tracing the Water-Energy-Food Nexus." Geography Compass 9, no. 8 (August 2015): 445-60. https://doi.org/10.1111/gec3.12222.

Marenya, P.P. and C.P. Barret, 2009. State-Conditional Fertilizer Yield Response on Western Kenyan Farms. Amer. J. Agr. Econ. 91(4) (November 2009): 991-1006

McKinnon, Alan, and Maja Piecyk. Measuring and Managing CO2 Emissions in European Chemical Transport. Report Prepared for Cefic. Logistics Research Centre Heriot-Watt University, 2010. http://www.cefic.be/files/publications/McKinnon-Report-Final230610.pdf.

Niger, Intended Nationally Determined Contribution (INDC). Document submitted to the Registry of Nationally Determined Contribution documents of the United Nations Framework Convention on Climate Change. (2015) http://www4.unfccc.int/ndcregistry/Pages/All.aspx, Accessed 7/25/2018

Patzek, Tad W. "Thermodynamics of the Corn-Ethanol Biofuel Cycle." Critical Reviews in Plant Sciences 23, no. 6 (November 2004): 519-67. https://doi.org/10.1080/07352680490886905. 
Pimentel, David. "Energy Inputs in Food Crop Production in Developing and Developed Nations." Energies 2, no. 1 (January 16, 2009): 1-24. https://doi.org/10.3390/en20100001.

Reij, Chris, Gray Tappan, and Melinda Smale. Agroenvironmental Transformation in the Sahel: Another Kind of "Green Revolution." IFPRI Discussion Paper 00914 00914. International Food Policy Research Institue, 2009.

Rhoades, C. "Seasonal Pattern of Nitrogen Mineralization and Soil Moisture beneath Faidherbia Albida in Central Malawi." Agroforestry Systems 29, no. 2 (February 1, 1995): 133-45. https://doi.org/10.1007/BF00704882.

Saka, A.R., W.T. Bunderson, O.A. Itimu, H.S.K. Phombeya, and Y. Mbekeani. "The Effects of Acacia Albida on Soils and Maize Grain Yields under Smallholder Farm Conditions in Malawi." Forest Ecology and Management 64, no. 2-3 (April 1994): 217-30. https://doi.org/10.1016/0378-1127(94)90296-8.

Shitumbanuma, Victor. Analyses of Crop Trials under Faidherbia albida. Results of Crop Yields for the 2010/2011 Agricultural Season and Overall Summary of Yields and Yield Trends from 2008 to 2011. Conservation Farming Unit, Department of Soil Science School of Agricultural Sciences University of Zambia, 2012 https://conservationagriculture.org/uploads/pdf/CFU-FAIDHERBIA-CROP-TRIALSShitumbanuma-Sep-2012.pdf.

Sileshi, Gudeta W. "The Magnitude and Spatial Extent of Influence of Faidherbia Albida Trees on Soil Properties and Primary Productivity in Drylands." Journal of Arid Environments 132 (September 1, 2016): 1-14. https://doi.org/10.1016/j.jaridenv.2016.03.002.

Simonsen, Morton, and Hans Jakob Walnum. "Energy Chain Analysis of Passenger Car Transport." Energies 4 (February 17, 2011): 324-51. https://doi.org/10.3390/en4020324.

Steffen, W., A. Sanderson, P.D. Tyson, J. Jager, P.A. Matson, B. Morre III, F. Oldfield, K. Richardson, H.J. Schellenhuber, B.L. Turner II, and R.J. Wason, 2005. Global Change and the Earth System: A Planet Under Pressure. Springer-Verlag, Berlin Heidelberg.

Umar, B. B., J. Aune, and O. Lungu. "Effects of Faidherbia Albida on the Fertility of Soil in Smallholder Conservation Agriculture Systems in Eastern and Southern Zambia." Afr $J$ Agric Res 8 (January 1, 2013): 173-83.

Warren, G. F. "Spectacular Increases in Crop Yields in the United States in the Twentieth Century." Weed Technology 12, no. 4 (1998): 752-60.

Wahl, Carl T., and William L. Bland. "Faidherbia Albida on the Tonga Plateau of Southern Zambia: An Agroecological Analysis." International Journal of Agricultural Sustainability 11, no. 4 (November 2013): 382-92. https://doi.org/10.1080/14735903.2013.812607. 
Yengwe, Jones, Mesfin Tsegaye Gebremikael, David Buchan, Obed Lungu, and Stefaan De Neve. "Effects of Faidherbia Albida Canopy and Leaf Litter on Soil Microbial Communities and Nitrogen Mineralization in Selected Zambian Soils." Agroforestry Systems, January 3, 2017. https://doi.org/10.1007/s10457-016-0063-4.

Yengwe, Jones, Okky Amalia, Obed Isaac Lungu, and Stefaan De Neve. "Quantifying Nutrient Deposition and Yield Levels of Maize ( Zea Mays ) under Faidherbia Albida Agroforestry System in Zambia." European Journal of Agronomy 99 (September 2018): 148-55.

https://doi.org/10.1016/j.eja.2018.07.004. 